\title{
EFFICACY OF DOXAZOSIN VERSUS TAMSULOSIN IN LOWER URETERIC STONE EXPULSION IN ADULT POPULATION OF DISTRICT DERA ISMAIL KHAN, PAKISTAN
}

Muhammad Seerwan', Ghazi Khan', Muhammad llyas', Dastgeer Waheed², Atta Ur Rehman³, Fawad Humayun ${ }^{4}$

Departments of ${ }^{1}$ Urology, ${ }^{2}$ General Surgery, Gomal Medical College, D.I.Khan, ${ }^{3}$ Departments of Urology, Nishtar Hospital , Multan, ${ }^{4}$ Department of Peadiatric Urology, The Children's Hospital \& The Institute of Child Health, Lahore, Pakistan

\section{ABSTRACT}

Background: Urolithiasis is the third common disease of the urinary tract after UTIs and pathological diseases of the prostate. The objective of this study was to compare the efficacy of doxazosin versus tamsulosin in lower ureteric stone expulsion in adult population of District Dera Ismail Khan, Pakistan.

Materials \& Methods: This non-randomized control trial was conducted in the Department of Urology, Gomal Medical College, Dera Ismail Khan, Pakistan from February 2020 to December 2020. The 252 patients included in our study were divided in to two groups. The patients in experimental group received Tab. doxazosin $4 \mathrm{mg}$ daily for 4 weeks and Tab. diclofenac sodium $50 \mathrm{mg} \mathrm{B.D}$ for 5 days and then on need basis. The patients in control group received Cap. tamsulosin $0.4 \mathrm{mg}$ daily for 4 weeks and similarly Tab. diclofenac sodium $50 \mathrm{mg}$ as in experimental group. All the patients were followed regularly for expulsion of ureteric stones for four weeks. Sex, age and stone size were matching, while stone expulsion was a research variable. Hypothesis was verified by McNemar chi-square test.

Results: Out of 252 patients, 113 (89.68\%) patients in experimental group, while 77 (61.11\%) patients in control group passed the stones. There was statistically significant difference in efficacy in doxazosin group as compared to tamsulosin group ( $p$-value $=<.0001$ ).

Conclusion: The use of doxazosin as the medical expulsion therapy for the lower ureteric stone proved to be more effective as compared to tamsulosin as demonstrated by our results.

KEY WORD: Lower Ureteric Stone; Doxazosin; Tamsulosin; Experimental Group; Control Group; Adult; Pakistan.

Cite as: Seerwan M, Khan G, Ilyas M, Waheed D, Rehman AU, Humayun F. Efficacy of doxazosin versus tamsulosin in lower ureteric stone expulsion in adult population of District Dera Ismail Khan, Pakistan. Gomal J Med Sci 2021 Oct-Dec; 19(4):141-5. https://doi.org/10.46903/gjms/19.04.942

\section{INTRODUCTION}

1.1 Background: Urolithiasis is one of the commonest diseases in urology. ${ }^{1}$ The prevalence of the urolithiasis is $1-15 \%$ approximately with different probability of having urinary stones depending upon age, sex, race and geographic location. ${ }^{2}$

\section{Corresponding Author:}

Dr. Muhammad Seerwan

Assistant Professor

Department of Urology

Gomal Medical College

D.I.Khan, Pakistan

E-mail: drmuhammadseerwan@gmail.com

$\begin{array}{ll}\text { Date Submitted: } & 05-01-2021 \\ \text { Date Revised: } & 02-07-2021 \\ \text { Date Accepted: } & 15-08-2021\end{array}$

Ureteral stones comprise approximately $20 \%$ of urolithiasis cases. ${ }^{3,4}$ Ureteric stones usually present with acute pain colicky in nature. ${ }^{1}$ Now we have different treatment options for the ureteric stones e.g. expectant (conservative), medical expulsion, extra corporeal shockwave lithotripsy, URS and conventional open surgery. Different less invasive treatment options are effective and safe but they are associated with the known complications and may cause unnecessary economic burden as significant proportion of stones pass spontaneouly. ${ }^{5}$ Comparatively treatment option that are conservative are simple in nature and cheap but can have different complications e.g. colicky pain (recurrent episodes), urinary tract infections and sometimes may lead to renal damage..$^{3,6}$

If we advise the conservative treatment option to a patient, different factors should be considered as for 
the expulsion of the stone. The two significant factors are the stone size and location of the stone within the ureter. As the stone size is one of the most significant parameters, ${ }^{7}$ regarding new guidelines, small stones i.e. size less than $5 \mathrm{~mm}$ have the chances approximately $68 \%$ to clear spontaneously. ${ }^{8}$ Second factor is the stone location in the ureter. Patients having distal ureteric stones have more chances to pass the stone than patients having proximal stones. ${ }^{7}$

A research demonstrated that the use of the drugs called medical expulsion therapy (MET) to facilitate stone passage improves the outcomes. Different previous options included furosemide, calcium channel blockers and corticosteroids, which have been evaluated as MET to improve ureteral stone expulsion with inconsistent results. ${ }^{9}$ Recently alpha-1 antagonists are considered to be the most effective drugs for MET based on the results of meta-analysis. ${ }^{10-13}$

The human ureter is supplied by three subtypes of alpha adrenoceptors i.e., $\alpha-1 a, \alpha-1 b$ and $\alpha-1 d$. In 2007, Itoh, et al. ${ }^{14}$ demonstrated the distribution of alpha receptor subtypes in the proximal ureter as " $\alpha-1 d \geq \alpha-1 a>\alpha-1 b$ ", on the other hand, in distal ureter, $\alpha-1 d$ expression was significantly higher than $\alpha-1 a$ and $\alpha-1 b$ expression. Various studies have been conducted on the role of the alpha blockers in expulsion of the lower ureteric stones. Tamsulosin is alpha blocker with several times more affinity for $\alpha-1 a$ than $\alpha-1 d$ and $\alpha-1 b$ and has shown impressive results in the expulsion of lower ureteric stones..$^{15,16}$

Celik, et al. ${ }^{17}$ in 2018 demonstrated the stone expulsion rate between alfuzosin, doxazosin, tamsulosin, silodosin and tadalafil in cases of lower ureteric stone as $78.1 \%, 75.7 \%, 76.5 \%, 88.6 \%$ and $90 \%$ respectively.

1.2 Research Objective: The objective of this study was to compare the efficacy of doxazosin versus tamsulosin in lower ureteric stone expulsion in adult population of District Dera Ismail Khan, Pakistan.

Research (Null) Hypothesis: There is no significant difference in the efficacy of doxazosin versus tamsulosin in lower ureteric stone expulsion in adult population of District Dera Ismail Khan, Pakistan.

1.4 Significance of study: This study will guide the urologists in treating lower ureteric stones as medical treatment has minimal complications and minimal cost. This will help us in decreasing the unnecessary surgical interventions in patients with lower ureteric stones.

\section{MATERIAL AND METHODS}

2.1 Design, Setting, Duration, Population \& Sampling: This non-randomized control trial was done in the Department of Urology, Gomal Medical College, Dera Ismail Khan, Pakistan from February 2020 to December 2020. We enlisted the patients from the urology outdoor and emergency of DHQ Teaching Hospital.
Sample size was calculated 248 by online calculator i.e. https://www.openepi.com/SampleSize/SSCohort.htm with $5 \%$ level of significance, $80 \%$ power of test and taking expected percentage of efficacy as $79.4 \%$ in doxazosin group ${ }^{18}$ vs. $62.5 \%$ in tamsulosin group ${ }^{19}$ in patients with lower ureteric stone. We enrolled 270 patients to overcome for lost to follow ups and drop outs, with 135 in each group. Sampling was done by non probability consecutive sampling.

Inclusion criterion was all adult (15-60 years) patients with lower ureteric stone 5-10 $\mathrm{mm}$ in size. Exclusion criteria were patients with febrile illness, severe pain uncontrolled with oral analgesics, history of urological surgical intervention in past two weeks and patients having active urinary tract infection.

2.2 Conduct of procedure: The consent from the patients was taken. The patients were divided in two groups; experimental group and control group by lottery method. The patients in experimental group received Tab. doxazosin $4 \mathrm{mg}$ daily for 4 weeks and Tab. diclofenac sodium $50 \mathrm{mg}$ B.D for 5 days and then on need basis for pain management. The patients in control group received Cap. tamsulosin 0.4 mg daily for 4 weeks and similarly Tab. diclofenac sodium $50 \mathrm{mg}$ as in experimental group. All the patients were followed regularly for expulsion of ureteric stones by X-ray KUB or CT KUB till four weeks.

2.3 Data Collection and Analysis Plan: Age in years, gender and the stone size were matching variables and the stone expulsion was our research variable. Age in years was on ratio scale and was analyzed by mean and SD. Sex and stone expulsion were two nominal variables and were analyzed by count and percentage. We had only posttest data, so hypothesis was tested by McNemar chi-square test with Yates correction for continuity. ${ }^{20-23}$ at alpha 0.5 by using GraphPad. ${ }^{24}$

\section{RESULTS}

Out of 270 patients with lower ureteric stones, we assigned 135 patients to each of the two groups. Four patients from the experimental group and five patients from the control group lost to follow up. Early surgical intervention was indicated in five patients from the experimental group and four from the control group and then these were dropped from the study. In each group 126 patients completed the study.

There were $82(65.07 \%)$ male patients and 44 (34.93\%) female patients in experimental group, while there were $76(60.32 \%)$ males and 50 (39.68\%) female patients in control group; approximately similar.

The mean age of the patients in experimental group was $33.45 \pm 12.23$ years and in the control group it was $36.38 \pm 10.28$ years with negligible difference.

The mean stone size was in the experimental group was $7.25 \pm 1.38(5-10) \mathrm{mm}$. In the control group it was $7.38 \pm 1.43(5-10) \mathrm{mm}$; comparable in the both groups. 
Table 1: Comparison of efficacy of doxazosin versus tamsulosin in lower ureteric stone expulsion in adult population of District Dera Ismail Khan, Pakistan

\begin{tabular}{|c|c|c|c|c|c|c|c|}
\hline Variables & \multicolumn{3}{|c|}{ Stone expulsion in experimental group } & \multirow{2}{*}{$\begin{array}{c}\text { Columns } \\
\text { Total }\end{array}$} & \multirow{2}{*}{$\begin{array}{l}\text { Chi-square } \\
\text { value }\end{array}$} & \multirow{2}{*}{$\begin{array}{l}\text { Degree of } \\
\text { freedom }\end{array}$} & \multirow{2}{*}{$p$-value } \\
\hline \multirow{3}{*}{$\begin{array}{l}\text { Stone expulsion } \\
\text { in control group }\end{array}$} & Attributes & Yes & No & & & & \\
\hline & Yes & 70 & 7 & 77 & \multirow{2}{*}{24.500} & \multirow{2}{*}{1} & \multirow{2}{*}{0.0001} \\
\hline & No & 43 & 6 & 49 & & & \\
\hline \multicolumn{2}{|l|}{ Rows Total } & 113 & 13 & 126 & \multicolumn{3}{|c|}{ Null hypothesis was rejected } \\
\hline
\end{tabular}

Stone expulsion was achieved in $113(89.68 \%)$ patients in experimental group and in 77 (61.11\%) patients in control group. Stone expulsion was not achieved in 13 patients in the experimental group and 49 patients in the control group. There was statistically significant difference between the groups, with significantly higher efficacy in doxazosin group as compared to tamsulosin group with $\mathrm{p}$-value of $<.0001$. (Table 1)

\section{DISCUSSION}

In our study the stone expulsion rate was $89.68 \%$ in doxazosin group, while in tamsulosin group it was $61.11 \%$. Our study showed that doxazosin was more effective than tamsulosin for lower ureteric stone expulsion in adult population of district Dera Ismail Khan, Pakistan.

The minimally invasive techniques i.e. ESWL and URS for ureteral stones are effective, but still they are invasive and costly and are associated with known complications. Medical expulsion has been recommended for the small distal ureteric stones according to the recent guidelines. We evaluated the current data on the safety and the efficacy of medical expulsion by a-blockers. Their mechanism of the action is by relaxation of the smooth muscles of the ureter and the evidence of the efficacy and low adverse effects suggest that $\alpha-1$ adrenergic antagonists ( $\alpha$-blockers) should be the initial treatment in patients with lower ureteric stones. ${ }^{25}$ Most of the studies have used tamsulosin (a selective alpha-1a blocker) which improves the spontaneous expulsion rate of distal ureteric calculus. ${ }^{6,9,16}$ Only few studies have described the use of doxazosin, which is a non selective a-1 adrenergic receptor blocker for expulsion of distal ureteric stones. Doxazosin is a drug with a proven efficacy and high specificity and sensitivity for the treatment of $\mathrm{BPH} .{ }^{26}$ So the present study was carried out to compare the efficacy of non selective alpha blockers vs. selective alpha blockers for expulsion of distal ureteric stone. Stone expulsion rate was higher in experimental group and the difference was statistically significant in favor of doxazosin. This increased expulsion rate may be due to blockage of all alpha-1 receptors by doxazosin as compared to tamsulosin which is more selective for alpha-1a than alpha-1d and least sensitive to alpha-1b.

As reported by Itoh et al. ${ }^{14}$ that expression of the $\alpha-1 d$ receptors was more in all regions of the ureter but was in the order of $\alpha-1 d \geq \alpha-1 a>\alpha-1 b$ in proximal and the middle ureter. They also showed that in the distal ureter, $\alpha-1 d$ subtype expression was significantly more than the $\alpha-1 a$ and the $\alpha-1 b$ expression.

Similar results were shown as our study by Zehri, et al. ${ }^{26}$ in 2010 , in which they demonstrated that stone expulsion rate in distal ureteric stone was $70 \%$ in doxazosin group as compared to placebo group in which it was $38 \%$ with significant difference $(p=.009)$. Similarly the doxazosin group had less morbidity as evidenced by pain scores and also had decreased time required for stone passage.

Similar to our results, Sen, et al. ${ }^{27}$ compared the different doses of doxazosin i.e. $4 \mathrm{mg}$ and $8 \mathrm{mg}$ with placebo in 66 patients with distal ureteric stone. All patients were randomly divided into three groups: group 1 included 25 patients receiving $4 \mathrm{mg}$ doxazosin, group 2 included 22 patients receiving $8 \mathrm{mg}$ doxazosin and group 3 consisted of 19 patients who were defined as control group and received only hydration and analgesics. The stone expulsion rate was $72 \%(18 / 25)$ in group $1,68.1 \%(15 / 22)$ in group 2 and $25.3 \%(5 / 19)$ in group 3 . They showed that stone expulsion rate was statistically significantly higher in group 1 and 2 as compared to control group. They also concluded that $4 \mathrm{mg}$ and $8 \mathrm{mg}$ of doxazosin were nearly equally effective in cases of lower ureteric stone.

Contrary to our results, Celik, et al. ${ }^{17}$ in 2018 demonstrated the difference between stone expulsion rate between alfuzosin, doxazosin, tamsulosin, silodosin and tadalafil in cases of lower ureteric stone. They showed the stone expulsion rate between the respective groups as $78.1 \%, 75.7 \%, 76.5 \%, 88.6 \%$ and $90 \%$ respectively. They showed similar results for doxazosin and tamsulosin $(p=0.44)$. 


\section{CONSLUSION}

The use of doxazosin as the medical expulsion therapy for the lower ureteric stone proved to be more effective as compared to tamsulosin as demonstrated by our results. It is recommended that the patients of the lower ureteric stone should be advised doxazosin therapy for improvement in the chances of stone passage.

\section{REFERENCES}

1. Marshall L, Stoller MD. Urinary stone disease. In: Tanagho EA, Mcaninch JW, Lue TF editors. Smith and Tanagho's General Urology. 18th ed. New York: McGraw Hill; 2013. p.249-59.

2. Margaret SP, Yair L. Urinary Lithiasis: Etiology, Epidemiology and Pathogenesis. In: Wein AJ, Kavoussi LR, Novick AC, et al. editors. Cambell-Walsh Ulrology. 10th ed. Collingwood, Canada: Saunders; 2011; p.12570.

3. García MA, Gutiérrez JD, Martínez MR, Gómez LS. Use of alfuzosin for expulsion of stones in the distal third of ureter. Actas Urol Esp 2009;33:1005-10. https://doi.org/10.4321/ S0210-48062009000900013

4. Ahmed AF, Al-Sayed AY. Tamsulosin versus alfuzosin in the treatment of patients with distal ureteral stones. Kor J Urol 2010;51:193-7. https:// doi.org/10.4111/kju.2010.51.3.193

5. Sáenz MJ, Alarcón RO, Redondo GE, Llanes GL, Crespo ML, Fernández ML, et al. Prognostic factors of spontaneous expulsion in ureteral lithiasis. Actas Urol Esp 2010;34:882-7. https:// doi.org/10.1016/S2173-5786(10)70218-3

6. Bensalah K, Pearle M, Lotan Y. Cost-effectiveness of medical expulsive therapy using alpha-blockers for the treatment of distal ureteral stones. Eur Urol 2008;53:411-8. https://doi. org/10.1016/j.eururo.2007.09.012

7. Sfoungaristos S, Kavouras A, Katafigiotis I, Perimenis P. Role of white blood cell and neutrophil counts in predicting spontaneous stone passage in patients with renal colic. BJU Int 2012;110:339-45. https://doi.org/10.1111/j.1464410X.2012.11014.X

8. Türk C, Knoll T, Petrik A, Sarica K, Straub M, Seitz C. EAU Guidelines on urolithiasis. March 2019. Available at: https://uroweb.org/wp-content/uploads/EAU-Guidelines-on-Urolithiasis-2019.pdf

9. Healy KA, Ogan K. Nonsurgical management of urolithiasis: an overview of expulsive therapy. J Endourol 2005;19:759-67. https://doi. org/10.1089/end.2005.19.759

10. Parsons KJ, Hergan LA, Sakamoto K, Lakin C. Efficacy of a-blockers for the treatment of ureteral stones. J Urol 2007;177:983-7. https://doi. org/10.1016/j.juro.2006.10.023

11. Singh A, Alter HJ, Littlepage A. A systematic review of medical therapy to facilitate passage of ureteral calculi. Ann Emerg Med 2007;50:552-63. https:// doi.org/10.1016/j.annemergmed.2007.05.015
12. Hollingsworth JM, Rogers MA, Kaufman SR, Bradford TJ, Saint S, Wei JT, et al. Medical therapy to facilitate urinary stone passage: a meta-analysis. Lancet 2006; 368: 1171-9. https:// doi.org/10.1016/S0140-6736(06)69474-9

13. Seitz C, Liatsikos E, Porpiglia F, Tiselius H-G, Zwergel $U$. Medical therapy to facilitate the passage of stones: what is the evidence? Eur Urol 2009;56:455-71. https://doi.org/10.1016/j. eururo.2009.06.012

14. Itoh Y, Kojima Y, Yasui T, Tozawa K, Sasaki S, Kohri K. Examination of alpha 1 adrenoceptor subtypes in the human ureter. Int $\mathrm{J}$ Urol 2007;14:749-53. https://doi.org/10.1111/j.1442-2042.2007.01812.x

15. Agrawal M, Gupta M, Gupta A, Agrawal A, Sarkari A, Lavania P. Prospective randomized trial comparing efficacy of alfuzosin and tamsulosin in management of lower ureteral stones. Urol 2009;73:706-9. https://doi.org/10.1016/j.urology.2008.11.013

16. Pricop C, Novac C, Negru D, llie C, Pricop A, Tanase V. Can selective alpha-blockers help the spontaneous passage of the stones located in the uretero-bladder junction? Rev Med Chir Soc Med Nat lasi 2004;108:128-33.

17. Celik S, Akdenis F, Afsar YM, Bozkurt O, Gursoy $B M$, Hacihasanoglu ML, et al. Tadalafil versus alpha blockers (alfuzosin, doxazosin, tamsulosin and silodosin) as medical expulsive therapy for $<10 \mathrm{~mm}$ distal and proximal ureteral stones. Arch Ital Urol Androl 2018 Jun;90(2):117-22. https://doi.org/10.4081/aiua.2018.2.117

18. Yu B, Zheng X, Sun Z, Cao P, Zhang J, Gao Z, et al. The safety and efficacy of doxazosin in medical expulsion therapy for distal ureteric calculi: A meta-analysis. PLoS ONE 2021;16(1): e0245741. https://doi.org/10.1371/journal. pone. 0245741

19. Pradhan MM, Sigdel PR, Parajuli P, Chudal S, Poudyal S, Chapagain S, et al. Efficacy of tamsulosin plus tadalafil versus tamsulosin as medical expulsive therapy for lower ureteric stones: a randomized controlled trial. Advances Urol 2020. Article ID 4347598. 5 pages. https:// doi.org/10.1155/2020/4347598

20. Zar JH. Biostatistical Analysis. 5th ed. Englewood Clifts, New Jersey: Prentice-Hall, Inc. p.127.

21. Pegano M, Gauvreau K. Principals of Biostatistics. 2nd ed. Boston, MA, USA: Cengage Learning; 2000. p.349-52

22. Shah HU, Gul H, Khan R, Marwat M. Urethrocutaneous fistula following Snodgrass versus two stage Aivar Bracka repair of distal penile hypospadias in male children: a randomized control trial. Gomal J Med Sci 2018;16:54-8. https://doi. org/10.46903/gjms/16.02.1284

23. Alam A, Rehman AU, Waheed D, Khan MH, Ahmad W, Bashir I, et al. Post-operative oral antibiotics in reducing frequency of surgical site infection following non-perforated appendectomy 
in population of South Waziristan Agency, Pakistan. Gomal J Med Sci 2021 Apr-Jun; 19(2):53-7. https://doi.org/10.46903/gjms/19.02.936

24. Motulsky HJ. GraphPad, QuickCalcs. McNemar's test to analyze experimental studies. GraphPad Software, San Diego, CA, USA [accessed 17 January 2021]. Available at: https://www.graphpad. com/quickcalcs/McNemar1.cfm

25. Tzortzis V, Mamoulakis C, Rioja J, Gravas S, Michel MC, de la Rosette JJ. Medical expulsive therapy for distal ureteral stones. Drugs 2009;69(6):677-92. https://doi.org/10.2165/00003495-20096906000003
26. Zehri AA, Ather MH, Abbas F, Biyabani SR. Preliminary study of efficacy of doxazosin as a medical expulsive therapy of distal ureteric stones in a randomized clinical trial. Urology 2010 Jun;75(6):1285-8. https://doi.org/10.1016/j. urology.2009.10.069

27. Sen H, Erturhan S, Sadioglu E, Bayrak O, Seckiner i. A comparison of efficacy of doxazosin 4 and $8 \mathrm{mg}$ in medical expulsive therapy of distal ureteral stones: a prospective randomized clinical trial. Urolithiasis 2017;45(5):461-4. https:// doi.org/10.1007/s00240-016-0927-0
CONFLICT OF INTEREST

Authors declare no conflict of interest. GRANT SUPPORT AND FINANCIAL DISCLOSURE None declared.

\section{AUTHORS' CONTRIBUTION}

The following authors have made substantial contributions to the manuscript as under:

Conception or Design:

Acquisition, Analysis or Interpretation of Data:

Manuscript Writing \& Approval:

MS, GK, MI

MS, GK, MI, DW, AUR, FH

MS, GK, MI, DW, AUR, FH

All the authors agree to be accountable for all aspects of the work in ensuring that questions related to the accuracy or integrity of any part of the work are appropriately investigated and resolved. 